\title{
Calsequestrin Distribution, Structure and Function, Its Role in Normal and Pathological Situations and the Effect of Thyroid Hormones
}

\author{
P. NOVÁK ${ }^{1}$, T. SOUKUP ${ }^{1}$ \\ ${ }^{1}$ Institute of Physiology, Academy of Sciences of the Czech Republic, v. v. i., Prague, Czech \\ Republic
}

Received March 5, 2010

Accepted November 2, 2010

On-line March 14, 2011

\section{Summary}

Calsequestrin is the main calcium binding protein of the sarcoplasmic reticulum, serving as an important regulator of $\mathrm{Ca}^{2+}$. In mammalian muscles, it exists as a skeletal isoform found in fast- and slow-twitch skeletal muscles and a cardiac isoform expressed in the heart and slow-twitch muscles. Recently, many excellent reviews that summarised in great detail various aspects of the calsequestrin structure, localisation or function both in skeletal and cardiac muscle have appeared. The present review focuses on skeletal muscle: information on cardiac tissue is given, where differences between both tissues are functionally important. The article reviews the known multiple roles of calsequestrin including pathology in order to introduce this topic to the broader scientific community and to stimulate an interest in this protein. Newly we describe our results on the effect of thyroid hormones on skeletal and cardiac calsequestrin expression and discuss them in the context of available literary data on this topic.

\section{Key words}

Skeletal and heart muscle - Calcium binding proteins • Calsequestrin • Muscle pathology • Thyroid hormones

\section{Corresponding author}

Tomáš Soukup, Institute of Physiology, Academy of Sciences of the Czech Republic, v. v. i., Vídeňská 1083, CZ-142 20 Prague, Czech Republic. Fax: +420-2-4106 2488. E-mail: tsoukup@biomed.cas.cz

\section{Introduction}

$\mathrm{Ca}^{2+}$ is one of the most important signalling molecules involved in various cellular processes (for review see Berchtold et al. 2000, Carafoli 2002, Berridge et al. 2003, Clapham 2007). It is regulated by many CaBPs functioning as $\mathrm{Ca}^{2+}$ effectors, sensors or buffers. About $200 \mathrm{CaBPs}$ are encoded by the human genome (Carafoli et al. 2001) and CSQ is the most abundant $\mathrm{CaBP}$ in the SR of skeletal and cardiac muscle (MacLennan and Wong 1971, for review see Beard et al. 2004). It is an acidic protein that binds $\mathrm{Ca}^{2+}$ with moderate affinity, but with high capacity. In skeletal muscles, calsequestrin provides a large pool of $\mathrm{Ca}^{2+}$ releasable from the $\mathrm{SR}$ and at the same time it maintains the concentrations of free $\mathrm{Ca}^{2+}$ at sufficiently low levels, which is important for easier and more efficient inward transport of the released $\mathrm{Ca}^{2+}$ by SERCA pumps as well as for the control of RyR activity itself.

\section{CSQ-like proteins in other tissues and organisms}

Beside skeletal and cardiac CSQ isoforms of higher vertebrates with known amino acid sequence, many proteins reacting with antibodies against the above isoforms and sharing often significant similarity in their primary structures were described in other tissues and in various other organisms. In higher vertebrates, such proteins were detected in rat smooth muscles from the aorta and stomach (Volpe et al. 1994) and in the guinea pig urinary bladder (Moore et al. 2004). Besides muscle 


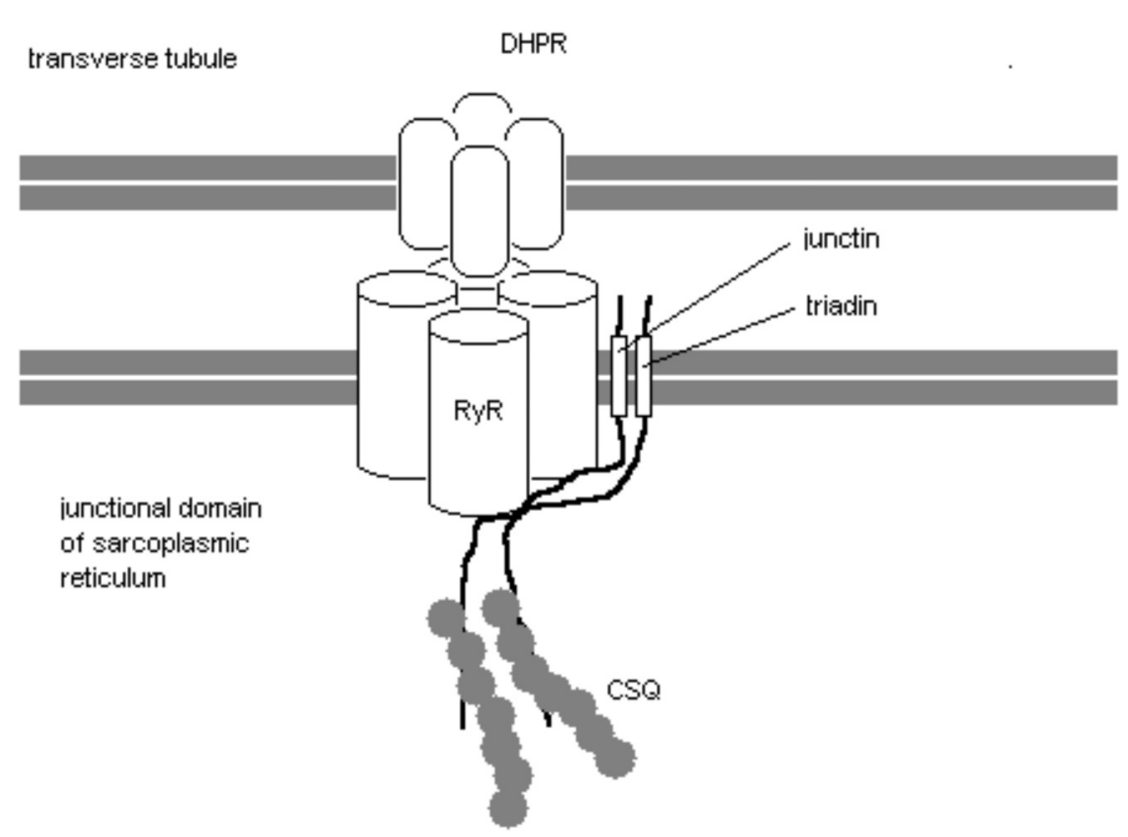

Fig. 1. A schematic representation of the SR junctional domain complex of the skeletal muscle connecting $T T$ and SR membranes, demonstrating organization of DHPRs, RyRs, triadin, junctin and CSQ.

tissue, high levels of CSQ-like proteins were detected in the Purkinje cells of chicken cerebellum (Volpe et al. 1991) and in the rat liver endoplasmic reticulum (Damiani et al. 1988). In invertebrates, a CSQ-like protein was found in body-wall muscle cells of Caenorhabditis elegans that shows moderate similarity ( $50 \%$ similarity, $30 \%$ identity) to rabbit SCSQ and is not essential for body-wall muscle formation and contraction (Cho et al. 2000). Another CSQ-like protein was purified from sea urchin (Strongylocentrotus droebachiensis and Arbacia punctulata) eggs, antigenically related to cCSQ, capable of binding anti-cCSQ antibody (Oberdorf et al. 1988). Furthermore, CSQ-like proteins were also discovered in some plant cells. A form of "CSQ" was detected in cultured Streptanthus tortuosus cells and spinach leaves recognised by antibodies against canine cCSQ (in S. tortuosus) and sCSQ (in spinach) (Krause et al. 1989). Additionally, a 42-kDa CSQ-like CaBP was found in calcium-accumulating cells of water lettuce (Pistia stratiotes) (Franceschi et al. 1993). Such widespread occurrence may suggest multiple functions of the "CSQ -like family" in various cells and tissues of diverse organisms. Their function in animal non-muscle cells and in plant cells remains, however, still in the realm of speculation.

\section{Ultrastructural localisation of CSQ}

As CSQ functions as an important part of ECC in muscle tissues (see further), it is important to know its ultrastructural localisation in situ. It was first described using indirect immunoferritin labelling of ultrathin frozen sections of rat skeletal muscle (gracilis). Most of the CSQ was found in the lumen of the terminal cisternae of the SR (Jorgensen et al. 1983). Corresponding localisations in the lumen of the peripheral and the interior junctional $\mathrm{SR}$ as well as in the lumen of the corbular SR were shown by indirect immunocolloidal gold labelling of ultrathin frozen sections in adult rat atrial and ventricular muscle cells (Jorgensen et al. 1985).

The architecture of the specialised junctional domain of the SR connecting it with the membrane of the TT system as revealed by electron microscopy was recently reviewed in great detail by Franzini-Armstrong (2009). She showed that the site facing the TT is occupied by a complicated molecular complex consisting of RyRs, two membrane-spanning proteins junctin and triadin (which mediate interactions of RyRs and CSQ) and CSQ, the main luminal protein (Fig. 1). She found that under the conditions prevailing within the SR lumen (physiological ionic strength, mostly due to $\mathrm{K}^{+}$and $\mathrm{Ca}^{2+}$ ions), CSQ forms long linear polymers and the fixed protein gel is clearly visible in the electron microscope. CSQ was found in this domain in all analysed muscles in a variety of vertebrate species (Damiani et al. 1986). In skeletal muscles, CSQ has a mostly diffuse configuration, appearing as a network of thin lines, while the considerably narrower junctional SR cisternae of cardiac muscles are filled with condensed CSQ (FranziniArmstrong 2009). Based on comparison of experiments with overexpression of CSQ ( 10-fold) targeted to cardiac muscle and null mutations of all three junctional 
domain proteins, Franzini-Armstrong (2009) suggests that the apparent difference between the skeletal and cardiac CSQ disposition and junctional domain appearance is not due to the difference in the presence of sCSQ versus cCSQ isoforms, but more likely due to the ratio of either CSQ isoform to triadin and junctin. These experiments, however, do not suggest whether there are differences in the total amount of these proteins between skeletal and cardiac muscle. Nonetheless, she concludes that a specific interaction of CSQ with triadin and junctin assures clustering of CSQ at the junctional domain and defines its specific architecture.

\section{Structure and $\mathrm{Ca}^{2+}$-binding characteristics of CSQ}

Rabbit sCSQ is encoded by a relatively small and uncomplicated gene that is only $8.6 \mathrm{~kb}$ long and contains 11 exons. The cloning and characterisation of the gene was described by Zarain-Herzberg et al. (1988), who also demonstrated the unlikeliness of alternative splicing of this gene. The molecule of rabbit sCSQ consists of three domains that form disk-like shapes and fold into $\alpha / \beta$ structures with a five-stranded mixed $\beta$-sheet in the core, flanked by four $\alpha$-helices. The domains are connected by short connecting loops (Wang et al. 1998).

The complete amino acid sequence of canine cCSQ was deduced by cDNA cloning. The following comparison showed that the nascent forms of adult canine cCSQ and adult rabbit sCSQ contain $63 \%$ identical residues (Scott et al. 1988). The cCSQ crystal structure is nearly superimposable on sCSQ which also applies to their front-to-front-type dimers (Park et al. 2004). Besides, Kim et al. (2007) reported the crystal structure of human cCSQ that is very similar to canine cCSQ and rabbit $\mathrm{SCSQ}$.

Generally the CSQ molecule exists as either a monomer or a wide range of high molecular mass clusters, depending on the ionic environment (Kim et al. 2007). As proposed by Park et al. (2003), $\mathrm{Ca}^{2+}$ regulation by CSQ involves an interplay among protein folding, $\mathrm{Ca}^{2+}$ binding, and CSQ polymerisation. Formation of ribbon-like linear polymers is permitted by front-to-front and back-to-back contacts between the CSQ monomers and is promoted by $\mathrm{Ca}^{2+}$ and inhibited by $\mathrm{K}^{+}$that induces CSQ folding. In the presence of $1 \mathrm{mM} \mathrm{Ca}^{2+}, \mathrm{cCSQ}$ is mostly monomer/dimer, while sCSQ is mostly polymerised (Wei et al. 2009).
The highly extended structure of CSQ becomes much more compact upon binding $\mathrm{Ca}^{2+}$ (Cozens and Reithmeier 1984). Binding $\mathrm{Ca}^{2+}$ is associated with a loss in protein hydrophobicity (the burying of hydrophobic amino acid side chains) and it prevents CSQ from interactions with other proteins. It also protects CSQ from proteolytic digestion. Canine cCSQ binds 800-900 nmol of $\mathrm{Ca}^{2+} / \mathrm{mg}$ of protein $\left(35-40 \mathrm{~mol}\right.$ of $\mathrm{Ca}^{2+} / \mathrm{mol}$ of CSQ) (Mitchell et al. 1988). A comparison of rabbit sCSQ and sheep cCSQ showed that $\mathrm{Ca}^{2+}$ binding to cCSQ is $50 \%$ lower than to sCSQ in spite of the fact that cCSQ contains an extended C-terminal tail (a part of the molecule binding $\mathrm{Ca}^{2+}$ ) composed of $>70 \%$ acidic residues (Wei et al. 2009).

The structure of CSQ appears to be the key to elucidating its interactions with other molecules and thus its function (for review and pictures demonstrating the CSQ structure and binding see e.g. Park et al. 2003, Beard et al. 2004, 2009).

\section{CSQ function and interaction within the membrane complex}

Both in skeletal and cardiac muscles, CSQ forms a quaternary complex with RyRs, junctin and triadin (Zhang et al. 1997, for review see Beard et al. 2009) that is involved in ECC, the process linking sarcolemma and T-tubule membrane depolarisation to $\mathrm{Ca}^{2+}$ release from the SR via the RyRs (for review see Sandow 1965, Murray et al. 1998, Dulhunty 2006, Beard et al. 2005, 2009, Mackrill 2010). CSQ in skeletal muscles thus localises calcium near the junctional face of SR terminal cisternae from which it can be released into the cytosol as a consequence of muscle stimulation by neuronal activity. Depolarisation following nerve impulses and spreading into deep infoldings of TTs activates DHPR calcium channels coupled with the RyR calcium release channels resident on the adjacent SR membrane. The DHPRs are supposed to induce $\mathrm{Ca}^{2+}$ release in skeletal muscles via direct physical interactions with the RyRs (Block et al. 1988, Franzini-Armstrong and Protasi 1997). Released calcium then binds to troponin $\mathrm{C}$ which relieves tropomyosin`s block of myosin/actin binding and starts a chain of reactions leading to muscle contraction (ECC). In vertebrate adult skeletal muscle fibres, contraction depends almost exclusively on $\mathrm{Ca}^{2+}$ released from the SR and not on the influx of extracellular $\mathrm{Ca}^{2+}$ (Melzer et al. 1995). In cardiac muscle, the RyRs are activated by $\mathrm{Ca}^{2+}$ that passes through the DHPRs from the extracellular 
space (for review see Beard et al. 2004, 2009, Dulhunty 2006, Chen et al. 2010). CSQ is thus a part of the highly specialised system controlling release and re-uptake of calcium and linking together two well organised membrane systems, the exterior sarcolemma with its transverse tubules and the internal SR membranes. CSQ plays its role as the main $\mathrm{CaBP}$ in accord with and dependent on its contact with triadin and junctin linking it to the RyRs. Together this complex can sense the $\mathrm{Ca}^{2+}$ concentration in cytoplasmic and SR lumen compartments, which enables appropriate regulation of $\mathrm{Ca}^{2+}$ store load and $\mathrm{Ca}^{2+}$ release via the RyRs.

Triadin binds specifically to the $\mathrm{RyR} / \mathrm{Ca}^{2+}$ release channel and CSQ (Guo and Campbell 1995) and its binding to the $\mathrm{C}$-terminal luminal loop of the RyR1 seems important for ensuring rapid $\mathrm{Ca}^{2+}$ release during ECC in skeletal muscle (Goonasekera et al. 2007). However, its role is not essential, as pan-triadin null mice have no obvious contractile dysfunction (Shen et al. 2007). Junctin got its name, because it is an integral component of the junctional SR membrane in both cardiac and skeletal muscle. A short N-terminal region of this $26-\mathrm{kDa}$ protein is located in the cytoplasm, and the bulk of the molecule projects into the SR lumen (Jones et al. 1995, for review see Dulhunty et al. 2009). Experiments on RyR1 terminal loop mutants revealed that junctin and triadin bind to different sites on RyR, thus elucidating the formation of the whole complex (Goonasekera et al. 2007).

Experiments on canine cardiac RyRs suggest that CSQ serves as a luminal Ca sensor that inhibits the RyR at low luminal calcium concentration and triadin 1 (the predominant triadin isoform in cardiac muscle) and/or junctin may be required to mediate interactions of CSQ with RyR (Györke et al. 2004). It was reported that the control of the RyR channels by CSQ in vitro is phosphorylation-dependent and that only dephosphorylated CSQ induces $\mathrm{Ca}^{2+}$ release from the SR (Szegedi et al. 1999). Later experiments showed, though, that under $1 \mathrm{mM}$ luminal calcium concentration and in the presence of triadin and junctin, phosphorylation of CSQ does not alter its ability to inhibit native RyR activity (Beard et al. 2005).

The ability of CSQ to regulate skeletal RyRs also depends on its polymerisation. It was shown that CSQ readily forms a wide range of high molecular mass clusters (Maguire et al. 1997, Kim et al. 2007) and that triadin is implicated in this process (Guo and Campbell 1995). Under physiological conditions, CSQ is polymerised and regulates the activity of the RyRs. Lowering of luminal $\mathrm{Ca}^{2+}$ from $1 \mathrm{mM}$ to $100 \mu \mathrm{M}$ for several minutes leads to sCSQ depolymerisation and dissociation of $65-75 \%$ of CSQ from the junctional face membrane resulting in a loss of CSQ regulation of the skeletal RyRs (Wei et al. 2006).

Calcium concentration, CSQ structure, formation of quarternary RyR-triadin-junctin-CSQ complexes and RyR activity itself are closely connected, which is a prerequisite for the fine tuning of the muscle contraction. Furthermore, similarly to the other channels, the complexes are strongly targeted by many drugs, opening prospects for pharmacological regulation of many pathological conditions and diseases including malignant hyperthermia, skeletal muscle myopathies, cardiac arrhythmias, epilepsy, neurodegeneration, pain and cancer (for review see Mackrill 2010).

\section{CSQ in fast and slow skeletal muscles and in the heart}

CSQ is produced in a skeletal and a cardiac isoform, which are products of two different genes (Scott et al. 1988, Fliegel et al. 1990). The proportion of both isoforms varies according to the muscle and species, the precise value is likely dependent on the proportion of fast type 2 and slow type 1 fibres in the given muscle (Murphy et al. 2009). The skeletal isoform (sCSQ, CSQ1) is the only isoform found in fast-twitch and is the major isoform in slow-twitch muscles, while the cardiac isoform (cCSQ, CSQ2) is the only transcript in cardiac muscle and a minor transcript in adult slow-twitch muscle (Fliegel et al. 1987 - fast, Scott et al. 1988 - cardiac, Biral et al. 1992, for review see Beard et al. 2004). The sCSQ:cCSQ ratio in the rabbit soleus muscle was reported to be $\sim 3: 1$ (Damiani et al. 1990) or higher (Fliegel et al. 1989). The sCSQ levels are much higher in fast- compared to slow-twitch muscles, as the amount of released calcium that must be taken up at a given moment is much higher in fast than in slow muscles. The content of sCSQ in homogenates of rat fast EDL and slow soleus was determined as $1.4 \pm 0.1$ and $0.43 \pm 0.3 \mathrm{mg} / \mathrm{g}$ muscle wet weight, respectively (Murphy et al. 2009). Maximal $\mathrm{Ca}^{2+}$ binding capacity was estimated as $\sim 80 \mathrm{~mol} / \mathrm{mol}$ of sCSQ and $\sim 60 \mathrm{~mol} / \mathrm{mol}$ of cCSQ (Park et al. 2004).

The general properties of sCSQ and cCSQ are similar (Beard et al. 2004). Both of them fulfil their main function as SR luminal $\mathrm{Ca}^{2+}$ sensors for the skeletal RyR1 (sCSQ) or cardiac RyR2 (cCSQ) isoform (Györke et al. 
2004, Wei et al. 2006, Qin et al. 2008). Structurally, the cCSQ isoforms differ mainly in having a highly extended acidic C-terminal tail. Most of our knowledge about differences of molecular interactions between SCSQ and cCSQ comes from studies of isolated systems. Experiments with the incorporation of microsomal vesicles (formed from terminal cisternae of the SR) into artificial lipid bilayers enabled the formation of a model of the SCSQ structure and regulation of RyR1 by $\mathrm{Ca}^{2+}$ concentration changes (Wei et al. 2006, 2009). Similar experiments on the heart showed that CCSQ binding to RyR2 under physiological conditions can be quite different (Wei et al. 2009). When SCSQ is added back to the luminal solution bathing lipid bilayers at a physiological $1 \mathrm{mM} \mathrm{Ca}^{2+}$ concentration it inhibits RyR 1 (Beard et al. 2002), while cCSQ activates RyR2 under the same conditions (Wei et al. 2009). Based on their extensive studies, Beard and colleagues concluded that the role of cCSQ in the heart can be quite different from that of SCSQ in skeletal muscles (Wei et al. 2009), although much less is known about molecular interactions of cCSQ and RyR2 (Beard et al. 2009). Similarly, they suggest the existence of differences in regulation of skeletal RyR1 by SCSQ in fast twitch and cCSQ in slow-twitch muscles (Beard et al. 2009).

\section{CSQ changes during postnatal development}

As already mentioned, skeletal and heart muscles differ in the mechanism of their activation by $\mathrm{Ca}^{2+}$. In the heart, contraction is initiated by membrane ionic current and spontaneous $\mathrm{SR} \mathrm{Ca}^{2+}$ release, while skeletal muscles derive all calcium required for contraction from their internal stores. In developing skeletal muscles, ECC is supposed to be similar to the "cardiac-like" mechanism and it becomes the "skeletal type" after maturation of the whole calcium handling system, including DHPRs, RyRs, SERCA and CSQ (Flucher and Franzini-Armstrong 1996, for review see Franzini-Armstrong 2009). It was shown in rabbits that during the development the cardiac/slow isoforms of these $\mathrm{Ca}^{2+}$ handling proteins are down-regulated and gradually replaced by their fast skeletal counterparts (Froemming and Ohlendieck 1998). Interestingly, the relation between both CSQ isoforms can be changed by 30 days of chronic low frequency electrostimulation that induces a slight down-regulation of "fast" SCSQ and increase of the relative density of "slow" cCSQ in microsomal preparations (Froemming et al. 2000). The
cCSQ is the only isoform expressed in the heart at all developmental stages. On the other hand, skeletal muscles express both CSQ isoforms, although the expression ratio between cCSQ and SCSQ isoforms is developmentally regulated and varies from muscle to muscle. During the development it is cCSQ that is the most abundant isoform in foetal and neonatal slow skeletal muscles, while in adults it is co-expressed in slow muscles with sCSQ. sCSQ is also already expressed in embryonic muscles, its levels are higher in presumptive fast-twitch muscles than in slow ones and they steeply increase before birth and reach adult values in both fast and slow muscles of the rabbit 4 days after birth (Leberer et al. 1986). In contrast to slow muscles, cCSQ completely disappears from fast muscles between two and four weeks postnatally and the SCSQ is supposed to be the only isoform in the adult animals (Leberer et al. 1986, Sacchetto et al. 1993).

\section{Pathological changes}

Much about CSQ function in skeletal and heart muscle can be learnt from knockouts and mutations expressing different levels of CSQ isoforms. In contrast to molecular interactions, where SCSQ in isolated systems has been mostly studied, the majority of the transgenic experiments were focused on cardiac myocytes. The mutations can strike at different loci and thus affect various CSQ functions including CSQ-RyR interactions and the $\mathrm{Ca}^{2+}$ buffering capacity. Furthermore, due to the differences in ECC even similar mutations in skeletal and cardiac isoforms can lead to different consequences.

Knockout mice lacking SCSQ are viable and fertile, capable of muscle contraction, although their skeletal muscles appear slightly atrophic. The preserved contraction is apparently achieved through adaptive changes in the muscle structure and protein composition (Paolini et al. 2007). Functional changes that are much more evident in fast-twitch muscles (EDL) with a great majority of fibres expressing only SCSQ than in slowtwitch muscles (soleus) expressing both skeletal and cardiac CSQ isoforms include prolonged rise and decay of tension, impaired $\mathrm{Ca}^{2+}$ release from the SR and decline in the amplitude of the $\mathrm{Ca}^{2+}$ transient, striking proliferation of SR junctional domains, large decrease in size of the junctional SR cisternae, higher density of mitochondria and increased density of $\mathrm{Ca}^{2+}$-release channels. It can be concluded that SCSQ is essential for 
the normal development of the SR and its calcium release units and for the storage and release of appropriate amounts of $\mathrm{SR}^{2}{ }^{2+}$. Also, cCSQ deletion mice are viable and maintain relatively normal $\mathrm{Ca}^{2+}$ release and contractile function, although they exhibit increase in SR volume and near absence of triadin-1 and junctin (Knollmann et al. 2006, 2009). It appears that the main role of cCSQ is to protect the heart against premature $\mathrm{Ca}^{2+}$ release and triggered arrhythmias and together with triadin it seems important for the structural organisation of the SR.

Transgenic mice exhibiting 10-fold higher levels of cCSQ in myocardium survived into adulthood, but had severe cardiac hypertrophy with 1.9-fold increase in heart mass (Jones et al. 1998). Their hearts adapted to CSQ overexpression by altering expression of other proteins. RyR, junctin, and triadin were down regulated by $50 \%$ or more, while $\mathrm{Ca}^{2+}$-ATPase and phospholamban were unchanged or slightly increased (Jones et al. 1998).

Transgenic mice (DBA/C57BL/6, 8 weeks old) with cardiac-specific overexpression of cCSQ developed chronic heart failure, cachexia, and exercise intolerance. Despite the latter effect, there was no significant change in skeletal muscle fibre-type composition, although fast glycolytic tibialis anterior and plantaris muscles underwent atrophy, whereas slow oxidative soleus muscle maintained muscle mass ( $\mathrm{Li}$ et al. 2007). This demonstrates that the observed changes in the ability of skeletal muscle to withstand increased physiological demands resulted from heart failure and not from cCSQ overexpression per se. This course can suggest that the changes of CSQ buffering occur first and are followed by the CSQ-RyR activity regulation (Jones et al. 1998). Altogether, the described changes of cCSQ resulting in severe deterioration of the heart performance showed only mild consequences in skeletal muscles (Li et al. 2007).

It seems that both up- and down-regulation of CSQ expression are compatible with life, although changes of calcium handling have particular effects on the structure and function especially of cardiac muscle. Interestingly, in the models of severe muscle dystrophies like dystrophic mdx mice lacking the dystrophin isoform Dp427, there are no changes in expression of CSQ, DHPRs, RyRs and SERCA. They, however, show drastic reduction of CSQ-like proteins of $150-220 \mathrm{kDa}$ in dystrophic microsomes (Culligan et al. 2002).

Changes in CSQ expression also result in many pathological changes in humans. A new type of surplus protein myopathy was described in four patients from four different families. It had benign evolution and was characterised by inclusions composed of an excess of SERCA1 (a SERCA isoform typical for fast-twitch skeletal muscles) and SCSQ (Tomelleri et al. 2006).

A significant association between SCSQ gene polymorphism and type 2 diabetes was found in the Old Order Amish, a strictly endogamous ethnoreligious group with a limited number of ancestors. This gene is encoded on chromosome 1q21, a region that has been linked to type 2 diabetes in diverse populations (Fu et al. 2004). Increased CSQ expression and calcium binding were reported in streptozotocin-induced diabetic rat skeletal muscle (entire hind limb skeletal muscles were investigated using anti-sCSQ antibody on Western blots) though not in their cardiac muscle (Howarth et al. 2002).

Various cCSQ (both missense and nonsense, Lahat et al. 2001, Postma et al. 2002) and RyR mutations (Marks et al. 2002, Györke 2009) cause the most significant CSQ related disease-catecholaminergic polymorphic ventricular tachycardia (CPVT). It is a familiar arrhythmogenic disorder manifested at a young age and characterised by syncopal events, seizures and sudden cardiac death during physical or emotional stress in absence of gross structural changes of the myocardium (Lahat et al. 2001, Postma et al. 2002, Terentyev et al. 2006, 2008). The CPVT-related cCSQ missense mutations lead to significant reduction in $\mathrm{Ca}^{2+}$-binding capacity and differences in $\mathrm{Ca}^{2+}$-dependent monomerpolymer transitions (Kim et al. 2007).

The aforementioned examples show that CSQ research is of great importance for biomedicine as it can be of great help in our understanding of various pathological conditions with possible practical implications.

Another pathological condition related to CaBPs is the alteration of the thyroid status. Antibodies against CSQ were found in $40 \%$ of patients with active thyroidassociated ophthalmopathy (a progressive orbital disorder associated with Graves' hyperthyroidism and, less often, Hashimoto's thyroiditis), but in $0 \%$ of normal subjects (Gunji et al. 1998). Recently it was announced that in patients with Graves' disease, both cCSQ and sCSQ genes were highly upregulated (Gopinath et al. 2009).

\section{CSQ expression in experimentally altered thyroid states}

Experimental studies analysing effects of thyroid hormone levels on CaBPs expression focused mainly on 
A

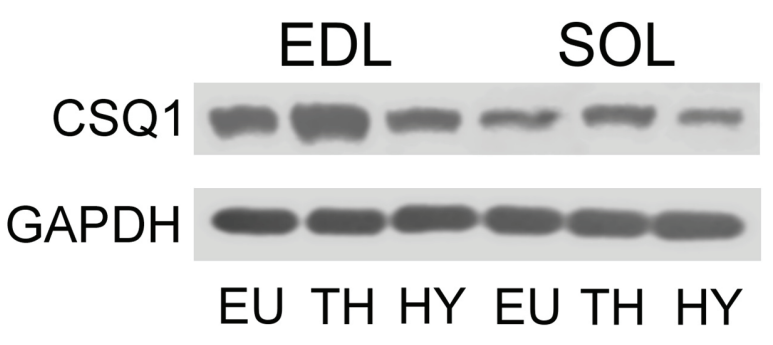

B

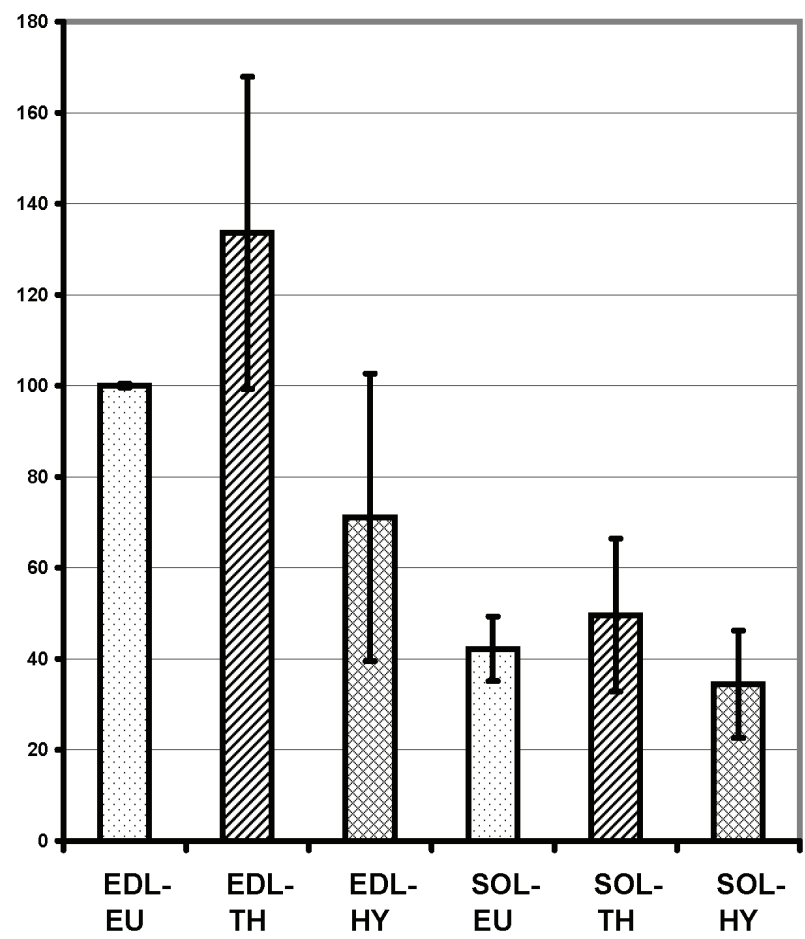

Fig. 2. (A) An illustrative Western blot of skeletal CSQ in the fast extensor digitorum longus (EDL) and slow soleus (SOL) skeletal muscles of euthyroid (EU), hyperthyroid ( $\mathrm{TH}$, treated with triiodothyronine) and hypothyroid (HY, treated with methimazole) 9- to 11-month-old inbred female Lewis strain rats. After separation of muscle proteins by SDS-PAGE, CSQ was revealed on western blots by specific monoclonal antibody. Corresponding amounts of GAPDH are shown in the bottom panel as loading control. (B) The mean content of skeletal CSQ compared relatively to the content in the EDL of EU rats. Results are expressed in arbitrary units adjusted to GAPDH expression. The data represent average values (means \pm S.D.) from 5 to 9 animals in each group; each value from an individual animal is based on 3 to 4 measurements (gels).

cardiac muscle apparently due to the profound impact of thyroid hormones on heart function mediated by regulating the transcription of genes for calcium transporter proteins of the sarcolemma and the SR and for specific myofibrillar proteins (for review see Dillmann 1990). Measurements of SERCA2, NCX and phospholamban in the rat heart showed that atria exhibit a greater change in the protein content than ventricles in response to triiodothyronine exposure (Shenoy et al. 2001). Much less is known about regulation of $\mathrm{Ca}^{2+}$ transport systems due to altered concentrations of thyroid hormones in skeletal muscle (e. g. Simonides and van Hardeveld 1985, Connelly et al. 1994). It was found that the hyperthyroid status increases and the hypothyroid status decreases protein and mRNA levels of RyR and SERCA after acute 4- or 8-day treatment in rabbits (Arai et al. 1991) and mRNA of RyR1 and 2, NCX and type 2 inositol-1, 4, 5-triphosphate receptors after chronic thyroid status alteration in rats (Hudecová et al. 2004). Studies related to CSQ changes in animals with altered thyroid status are exceptional. Arai et al. (1991) found that the acute changes of the thyroid status for 4 and 8 days in the rabbit soleus might suggest that hyperthyroidism increased expression of sCSQ compared to CCSQ, while hypothyroidism had rather the opposite effect. The same authors reported that cCSQ expression in rabbit ventricles was only slightly increased after both treatments and their results also implied possible differences in cCSQ expression between ventricles and atria.

In order to better understand the chronic effects of thyroid hormone alterations, we investigated expression of SCSQ and cCSQ and the fibre type composition in fast and slow skeletal muscles and the former also in the heart of euthyroid, hypothyroid and hyperthyroid adult inbred female Lewis strain rats at mRNA and/or protein levels. The HY status was induced with $0.05 \%$ solution of methimazole (2-mercapto-1methylimidazole, Sigma) in drinking water, the TH status by intraperitoneal injections of 3, 3', 5-triiodo-Lthyronine (Sigma, sodium salt, T3, $150 \mu \mathrm{g} / \mathrm{kg}$ body weight) 3 times a week (cf. Soukup et al. 2001). CSQ isoforms were determined by SDS-PAGE followed by western blot analysis (expression was normalised to GAPDH and $\mathrm{CBB}$ ) and gene expression was assessed using reverse transcription and subsequent real-time polymerase chain reaction. Our pilot experiments (Novák et al. 2008, 2010a) in agreement with previous findings in the rat (Murphy et al. 2009) show that the protein and transcript levels for SCSQ are the highest in the fast extensor digitorum longus (EDL), intermediate in the soleus (Fig. 2) and hardly detectable in the heart (not shown). The hypothyroid status decreases and the hyperthyroid status increases the already high protein levels of sCSQ in the fast EDL (Fig. 2). Neither the hypothyroid nor hyperthyroid status, however, has a marked effect on the "intermediate" levels of SCSQ found 
Table 1. Fibre type composition of the extensor digitorum longus (EDL) and soleus (SOL) muscles as determined by mATPase reaction at $\mathrm{pH} 4.5$ from 9- to 11-month-old euthyroid (EU), hypothyroid (HY, treated with methimazole) and hyperthyroid (TH, treated with triiodothyronine) female inbred Lewis strain rats (the same set as analysed for the CSQ in Fig. 2). The numerical proportions (\%) of muscle fibre types were assessed by 2-D stereological methods using the principles of an unbiased counting frame and point counting by the C.A.S.T. Grid System (Olympus, Albertslund, Denmark) (Zacharova and Kubinova 1995, Zacharova et al. 1997, 1999, 2005). $\mathrm{n}=$ number of muscles analysed. ${ }^{*} \mathrm{p} \leq 0.05,{ }^{* *} \mathrm{p} \leq 0.01,{ }^{* * *} \mathrm{p} \leq 0.001$ compared to the EU rats. The significance of the differences was evaluated by the Student's t-test and/or Mann-Whitney test.

\begin{tabular}{llll}
\hline THYROID STATUS & HY & EU & TH \\
\hline $\boldsymbol{E D L}$ & $n=13$ & $n=20$ & $n=10$ \\
1 & $9.7 \pm 5.3^{*}$ & $6.2 \pm 3.7$ & $2.2 \pm 2.0^{* * *}$ \\
$2 A$ & $23.6 \pm 7.9^{* *}$ & $15.8 \pm 3.8$ & $15.9 \pm 4.6$ \\
$2 B$ & $66.7 \pm 10.4^{* * *}$ & $78.0 \pm 5.2$ & $82.0 \pm 5.3$ \\
\hline $\boldsymbol{S O L}$ & $n=13$ & $n=24$ & $n=8$ \\
1 & $99.6 \pm 1.2$ & $99.2 \pm 1.2$ & $65.7 \pm 7.2^{* * *}$ \\
$2 A$ & $0.4 \pm 1.2$ & $0.8 \pm 1.2$ & $34.3 \pm 7.2^{* * *}$ \\
\hline
\end{tabular}

in the soleus muscle (Fig. 2) and on the practically nondetectable levels in the heart (not shown). A corresponding proportion of sCSQ expression under all thyroid states was attained when the values were expressed either to GAPDH (Fig. 2) or CBB (not shown). The mRNA levels for cCSQ are highest in the heart, intermediate in the soleus and lowest in the EDL muscle and in the latter they appear slightly increased in the hypothyroid status (Novák et al. 2008, 2010a).

It is worth to remember here the difference between heart and skeletal muscles exposed to increased levels of thyroid hormones. While in the heart hyperthyroidism leads to cardiac hypertrophy due to the increased haemodynamic load, skeletal muscles are not subjected to this change. On the other hand, skeletal muscles react to thyroid hormone alteration by modification of their fibre type composition and MyHC content (d'Albis and Butler-Browne 1993, Larsson et al. 1994, Vadászová et al. 2004, 2006a, b, VadászováSoukup and Soukup 2007, Soukup et al. 2009, for review see Soukup and Jirmanová 2000).

Skeletal muscle fibre types can be recognised by immunostaining with specific monoclonal antibodies against each MyHC isoform (Smerdu and Soukup 2008, Soukup et al. 2002, 2009) or by their mATPase activity (Soukup et al. 2009, Novák et al. 2010b). Using the latter for the rat, the fibres that stain positively after acid preincubations at $\mathrm{pH} 4.3$ and 4.5 of the mATPase reaction are classified as type I fibres, while the fibres that stain positively after the alkaline preincubation at $\mathrm{pH} 10.3$ and remain unstained after both acid preincubations at $\mathrm{pH} 4.3$ and 4.5 are type $2 \mathrm{~A}$ fibres and the fibres characterised by high mATPase activity after preincubation at $\mathrm{pH} 10.3$ and by moderate staining after preincubation at $\mathrm{pH} 4.5$ are $2 \mathrm{~B}$ fibres. Classification by $\mathrm{mATPase}$ reaction thus allows determination of type $1,2 \mathrm{~A}$ and $2 \mathrm{~B}$ fibres (containing most of $2 \mathrm{X} / \mathrm{D}$ fibres), while the more modern immunohistochemical approach reveals four types: type 1, 2A, 2X/D and 2B fibres (for review see e.g. Hämäläinen and Pette 1993, Schiaffino and Reggiani 1996, Soukup and Jirmanová 2000, Pette and Staron 2000, 2001, Pette 2002, Schiaffino 2010).

The EDL muscle of Lewis strain rats contains a low number of slow type 1 fibres (about $5 \%$ ), a higher number of $2 \mathrm{~A}$ fibres (about $15 \%$ ) and predominantly (almost $80 \%$ ) of the fastest 2B fibres (Table 1 EDL, Soukup et al. 2009, Novák et al. 2010b). On the other hand, the soleus muscle of the Lewis strain rats is composed of a great majority of slow-twitch or type 1 fibres (about 95 to $99 \%$ ) complemented by a variable number of fast-twitch 2A fibres (Table 1 SOL, Soukup et al. 2009, Novák et al. 2010b). Our preliminary comparison of fibre type and CSQ level changes indicates that the observed increase of the sCSQ level can be caused by the increase of the fastest $2 \mathrm{~B}$ fibres in the hyperthyroid status (where they form more than $80 \%$ of all the fibres), while the decreased level of sCSQ in the hypothyroid rats can result from a decline in the proportion of these fibres (Table 1 EDL). No changes of the sCSQ levels in the soleus can be explained by the lack of the fastest $2 \mathrm{~B}$ fibres and the significant increase of $2 \mathrm{~A}$ fibres in the hyperthyroid soleus has surprisingly only a small and non-significant effect on the increase of the sCSQ level. Similarly, Murphy et al. (2009) found more 
than a $3 x$ higher content of SCSQ in EDL type 2 fibres compared to soleus type 1 fibres and they also presumed the existence of differences in SCSQ levels between subgroups of fast type 2 fibres. Our results thus suggest that the observed changes in expression of SCSQ in rat muscles resulting from chronic alteration of thyroid hormone levels are more likely a part of complex fibre type changes induced by thyroid hormones and revealed by the switch of MyHC isoforms and muscle fibre types. The twitch profile is to a large extent dictated by SR properties and apparently the appearance of the SR reflects the CSQ content. Schiaffino et al. 1970 found that most fibres in the EDL muscle have a richly developed SR, which is consistent with a rapid calcium release and uptake during the contraction-relaxation cycle, in contrast to the major type 1 slow fibres of the soleus muscle with a relatively poorly developed SR. Normalisation of CSQ to GAPDH, which is a cytosolic housekeeping protein, may reflect changes in the content of the SR, which are likely to be affected by thyroid hormone changes in accordance with fibre type changes. Because we received in both muscles in different thyroid states the same proportion of SCSQ expression adjusted to $\mathrm{CBB}$ as to GAPDH and because all fast EDL fibres posses rich SR, we believe that the observed changes might reflect the relative abundance of CSQ within the SR associated with different sCSQ levels in different fibre types.

The effect of triiodothyronine levels on CSQ gene transcription would thus be regulated co-ordinately with other proteins rebuilt during muscle fibre type transformation and the expression of SCSQ apparently proceeds in a fibre type-specific manner. The final answer can, however, be obtained only by a single fibre analysis of MyHC isoforms and the SCSQ content.

\section{Conclusions}

Mammalian skeletal and cardiac CSQ isoform genes as well as the structure of the respective protein are relatively simple, but the protein is well suited to bind both $\mathrm{Ca}^{2+}$ and other proteins like RyRs, junctin and triadin, which strongly enhances CSQ`s ability to regulate calcium movements. Because of the central role of CSQ in $\mathrm{Ca}^{2+}$ regulation, it is not surprising that mutations of its gene and disturbances of its structure have various pathological consequences. Experiments relating to thyroid hormone levels suggest that SR calcium storage capacity (CSQ) is less affected than calcium release (RyRs) and uptake (SERCA, NCX) and that minor changes observed in muscles of rats with altered hormone levels are probably related to complex changes taking part during muscle fibre type transformation. The involvement of CSQ in thyroid hormone-related alterations of the calcium homeostasis thus remains an open question. Further studies are needed to reveal more about CSQ structural and functional modifications and their physiological role in the regulation of $\mathrm{Ca}^{2+}$ homeostasis.

\section{Conflict of Interest}

There is no conflict of interest.

\section{Acknowledgements}

Supported by MYORES No. 511978, MSMT CR LC554 and GACR 304/08/0256 grants and by the Research project AV0Z 50110509. We acknowledge the collaboration of Dr Vadym Sulimenko and Dr Vladimira Marková in CSQ protein and mRNA analysis, respectively, and Dr Gisela Zacharova for statistical analysis of muscle fibre type composition.

$\begin{array}{ll}\text { Abbreviations } \\ \text { CaBP } & \text { calcium binding protein } \\ \text { CBB } & \text { Coomassie Brilliant Blue } \\ \text { cCSQ } & \text { cardiac calsequestrin } \\ \text { DHPR } & \text { dihydropyridine receptor } \\ \text { ECC } & \text { excitation-contraction coupling } \\ \text { GAPDH } & \text { glyceraldehyde 3-phosphate dehydrogenase } \\ \text { NCX } & \mathrm{Na}^{+} / \mathrm{Ca}^{2+} \text { exchanger } \\ \text { RyR } & \text { ryanodine receptor } \\ \text { sCSQ } & \text { skeletal calsequestrin } \\ \text { SERCA } & \text { sarco/endoplasmic reticulum } \mathrm{Ca}^{2+} \text {-ATPase } \\ \text { SR } & \text { sarcoplasmic reticulum } \\ \text { TT } & \text { transverse tubule }\end{array}$

\section{References}

ARAI M, OTSU K, MACLENNAN DH, ALPERT NR, PERIASAMY M: Effect of thyroid hormone on the expression of mRNA encoding sarcoplasmic reticulum proteins. Circ Res 69: 266-276, 1991.

BERCHTOLD MW, BRINKMEIER H, MÜNTENER M: Calcium ion in skeletal muscle: its crucial role for muscle function, plasticity, and disease. Physiol Rev 80: 1215-1265, 2000. 
BEARD NA, SAKOWSKA MM, DULHUNTY AF, LAVER DR: Calsequestrin is an inhibitor of skeletal muscle ryanodine receptor calcium release channels. Biophys $J$ 82: 310-320, 2002.

BEARD NA, LAVER DR, DULHUNTY AF: Calsequestrin and the calcium release channel of skeletal and cardiac muscle. Prog Biophys Mol Biol 85: 33-69, 2004.

BEARD NA, CASAROTTO MG, WEI L, VARSÁNYI M, LAVER DR, DULHUNTY AF: Regulation of ryanodine receptors by calsequestrin: effect of high luminal $\mathrm{Ca}^{2+}$ and phosphorylation. Biophys $J$ 88: 3444-3454, 2005.

BEARD NA, WEI L, DULHUNTY AF: $\mathrm{Ca}(2+)$ signaling in striated muscle: the elusive roles of triadin, junctin, and calsequestrin. Eur Biophys J 39: 27-36, 2009.

BERRIDGE MJ, BOOTMAN MD, RODERICK HL: Calcium signalling: dynamics, homeostasis and remodelling. Nat Rev Mol Cell Biol 4: 517-529, 2003.

BIRAL D, VOLPE P, DAMIANI E, MARGRETH A: Coexistence of two calsequestrin isoforms in rabbit slow-twitch skeletal muscle fibers. FEBS Lett 299: 175-178, 1992.

BLOCK BA, IMAGAWA T, CAMPBELL KP, FRANZINI-ARMSTRONG C: Structural evidence for direct interaction between the molecular components of the transverse tubule/sarcoplasmic reticulum junction in skeletal muscle. J Cell Biol 107: 2587-2600, 1988.

CARAFOLI E, SANTELLA L, BRANCA D, BRINI M: Generation, control, and processing of cellular calcium signals. Crit Rev Biochem Mol Biol 36: 107-260, 2001.

CARAFOLI E: Calcium signaling: a tale for all seasons. Proc Natl Acad Sci U S A 99: 1115-1122, 2002.

CHEN PS, JOUNG B, SHINOHARA T, DAS M, CHEN Z, LIN SF: The initiation of the heart beat. Circ J 74: 221$225,2010$.

CHO JH, OH YS, PARK KW, YU J, CHOI KY, SHIN J, KIM DH, PARK WJ, HAMADA T, KAGAWA H, MARYON EB, BANDYOPADHYAY J, AHNN J: Calsequestrin, a calcium sequestering protein localized at the sarcoplasmic reticulum, is not essential for body-wall muscle function in Caenorhabditis elegans. $J$ Cell Sci 113: 3947-3958, 2000.

CLAPHAM DE: Calcium signaling. Cell 131: 1047-1058, 2007.

CONNELLY TJ, EL-HAYEK R, SUKHAREVA M, CORONADO R: L-thyroxine activates the intracellular Ca ${ }^{2+}$ release channel of skeletal muscle sarcoplasmic reticulum. Biochem Mol Biol Int 32: 441-448, 1994.

COZENS B, REITHMEIER RA: Size and shape of rabbit skeletal muscle calsequestrin. J Biol Chem 259: 6248-6252, 1984.

CULLIGAN K, BANVILLE N, DOWLING P, OHLENDIECK K: Drastic reduction of calsequestrin-like proteins and impaired calcium binding in dystrophic mdx muscle. J Appl Physiol 92: 435-445, 2002.

D'ALBIS A, BUTLER-BROWNE G: The hormonal control of myosin isoform expression in skeletal muscle of mammals: a review. Basic Appl Myol 3: 7-16, 1993.

DAMIANI E, SALVATORI S, ZORZATO F, MARGRETH A: Characteristics of skeletal muscle calsequestrin: comparison of mammalian, amphibian and avian muscles. J Muscle Res Cell Motil 7: 435-445, 1986.

DAMIANI E, SPAMER C, HEILMANN C, SALVATORI S, MARGRETH A: Endoplasmic reticulum of rat liver contains two proteins closely related to skeletal sarcoplasmic reticulum Ca-ATPase and calsequestrin. $J$ Biol Chem 263: 340-343, 1988.

DAMIANI E, VOLPE P, MARGRETH A: Coexpression of two isoforms of calsequestrin in rabbit slow-twitch muscle. J Muscle Res Cell Motil 11: 522-530, 1990.

DILLMANN WH: Biochemical basis of thyroid hormone action in the heart. Am J Med 88: 626-630, 1990.

DULHUNTY AF: Excitation-contraction coupling from the 1950s into the new millennium. Clin Exp Pharmacol Physiol 33: 763-772, 2006.

DULHUNTY A, WEI L, BEARD N: Junctin - the quiet achiever. $J$ Physiol 587: 3135-3137, 2009.

FLIEGEL L, OHNISHI M, CARPENTER MR, KHANNA VK, REITHMEIER RA, MACLENNAN DH: Amino acid sequence of rabbit fast-twitch skeletal muscle calsequestrin deduced from cDNA and peptide sequencing. Proc Natl Acad Sci U S A 84: 1167-1171, 1987.

FLIEGEL L, LEBERER E, GREEN NM, MACLENNAN DH: The fast-twitch muscle calsequestrin isoform predominates in rabbit slow-twitch soleus muscle. FEBS Lett 242: 297-300, 1989. 
FLIEGEL L, NEWTON E, BURNS K, MICHALAK M: Molecular cloning of cDNA encoding a 55-kDa multifunctional thyroid hormone binding protein of skeletal muscle sarcoplasmic reticulum. $J$ Biol Chem 265 : 15496-15502, 1990.

FLUCHER BE, FRANZINI-ARMSTRONG C: Formation of junctions involved in excitation-contraction coupling in skeletal and cardiac muscle. Proc Natl Acad Sci U S A 93: 8101-8106, 1996.

FRANCESCHI VR, LI X, ZHANG D, OKITA TW: Calsequestrinlike calcium-binding protein is expressed in calciumaccumulating cells of Pistia stratiotes. Proc Natl Acad Sci U S A 90: 6986-6990, 1993.

FRANZINI-ARMSTRONG C, PROTASI F: Ryanodine receptors of striated muscles: a complex channel capable of multiple interactions. Physiol Rev 77: 699-729, 1997.

FRANZINI-ARMSTRONG C: Architecture and regulation of the $\mathrm{Ca}^{2+}$ delivery system in muscle cells. Appl Physiol Nutr Metab 34: 323-327, 2009.

FROEMMING GR, OHLENDIECK K: Oligomerisation of $\mathrm{Ca}^{2+}$-regulatory membrane components involved in the excitation-contraction-relaxation cycle during postnatal development of rabbit skeletal muscle. Biochim Biophys Acta 1387: 226-238, 1998.

FROEMMING GR, MURRAY BE, HARMON S, PETTE D, OHLENDIECK K: Comparative analysis of the isoform expression pattern of $\mathrm{Ca}^{2+}$-regulatory membrane proteins in fast-twitch, slow-twitch, cardiac, neonatal and chronic low-frequency stimulated muscle fibers. Biochim Biophys Acta 1466: 151-168, 2000.

FU M, DAMCOTT CM, SABRA M, POLLIN TI, OTT SH, WANG J, GARANT MJ, O'CONNELL JR, MITCHELL BD, SHULDINER AR: Polymorphism in the calsequestrin 1 (CASQ1) gene on chromosome 1q21 is associated with type 2 diabetes in the old order Amish. Diabetes 53: 3292-3299, 2004.

GOONASEKERA SA, BEARD NA, GROOM L, KIMURA T, LYFENKO AD, ROSENFELD A, MARTY I, DULHUNTY AF, DIRKSEN RT: Triadin binding to the C-terminal luminal loop of the ryanodine receptor is important for skeletal muscle excitation contraction coupling. J Gen Physiol 130: 365-378, 2007.

GOPINATH B, WESCOMBE L, NGUYEN B, WALL JR: Can autoimmunity against calsequestrin explain the eye and eyelid muscle inflammation of thyroid eye disease? Orbit 28: 256-261, 2009.

GUNJI K, KUBOTA S, SWANSON J, KILJANSKI J, BEDNARCZUK T, WENGROWICZ S, SALVI M, WALL JR: Role of the eye muscles in thyroid eye disease: identification of the principal autoantigens. Thyroid 8: 553-556, 1998.

GUO W, CAMPBELL KP: Association of triadin with the ryanodine receptor and calsequestrin in the lumen of the sarcoplasmic reticulum. J Biol Chem 270: 9027-9030, 1995.

GYÖRKE I, HESTER N, JONES LR, GYÖRKE S: The role of calsequestrin, triadin, and junctin in conferring cardiac ryanodine receptor responsiveness to luminal calcium. Biophys $J$ 86: 2121-2128, 2004.

GYÖRKE S: Molecular basis of catecholaminergic polymorphic ventricular tachycardia. Heart Rhythm 6: 123-129, 2009.

HÄMÄLÄINEN N, PETTE D: The histochemical profiles of fast fiber types IIB, IID, and IIA in skeletal muscles of mouse, rat, and rabbit. J Histochem Cytochem 41: 733-743, 1993.

HOWARTH FC, GLOVER L, CULLIGAN K, QURESHI MA, OHLENDIECK K: Calsequestrin expression and calcium binding is increased in streptozotocin-induced diabetic rat skeletal muscle though not in cardiac muscle. Pflügers Arch-Eur J Physiol 444: 52-58, 2002.

HUDECOVÁ S, VADÁZOVÁ A, SOUKUP T, KRIŽANOVÁ O: Effect of thyroid hormones on the gene expression of calcium transport systems in rat muscle. Life Sci 75: 923-931, 2004.

JONES LR, ZHANG L, SANBORN K, JORGENSEN AO, KELLEY J: Purification, primary structure, and immunological characterization of the $26-\mathrm{kDa}$ calsequestrin binding protein (junctin) from cardiac junctional sarcoplasmic reticulum. J Biol Chem 270: 30787-30796, 1995.

JONES LR, SUZUKI YJ, WANG W, KOBAYASHI YM, RAMESH V, FRANZINI-ARMSTRONG C, CLEEMANN L, MORAD M: Regulation of $\mathrm{Ca}^{2+}$ signaling in transgenic mouse cardiac myocytes overexpressing calsequestrin. J Clin Invest 101: 1385-1393, 1998.

JORGENSEN AO, SHEN AC, CAMPBELL KP, MACLENNAN DH: Ultrastructural localization of calsequestrin in rat skeletal muscle by immunoferritin labeling of ultrathin frozen sections. J Cell Biol 97: 1573-1581, 1983.

JORGENSEN AO, SHEN AC, CAMPBELL KP: Ultrastructural localization of calsequestrin in adult rat atrial and ventricular muscle cells. J Cell Biol 101: 257-268, 1985. 
KIM E, YOUN B, KEMPER L, CAMPBELL C, MILTING H, VARSANYI M, KANG C: Characterization of human cardiac calsequestrin and its deleterious mutants. J Mol Biol 373: 1047-1057, 2007.

KNOLLMANN BC, CHOPRA N, HLAING T, AKIN B, YANG T, ETTENSOHN K, KNOLLMANN BE, HORTON KD, WEISSMAN NJ, HOLINSTAT I, ZHANG W, RODEN DM, JONES LR, FRANZINI-ARMSTRONG C, PFEIFER K: Casq2 deletion causes sarcoplasmic reticulum volume increase, premature $\mathrm{Ca}^{2+}$ release, and catecholaminergic polymorphic ventricular tachycardia. J Clin Invest 116: 2510-2520, 2006.

KNOLLMANN BC: New roles of calsequestrin and triadin in cardiac muscle. J Physiol 587: 3081-3087, 2009.

KRAUSE KH, CHOU M, THOMAS MA, SJOLUND RD, CAMPBELL KP: Plant cells contain calsequestrin. $J$ Biol Chem 264: 4269-4272, 1989.

LAHAT H, PRAS E, OLENDER T, AVIDAN N, BEN-ASHER E, MAN O, LEVY-NISSENBAUM E, KHOURY A, LORBER A, GOLDMAN B, LANCET D, ELDAR M: A missense mutation in a highly conserved region of CASQ2 is associated with autosomal recessive catecholamine-induced polymorphic ventricular tachycardia in Bedouin families from Israel. Am J Hum Genet 69: 1378-1384, 2001.

LARSSON L, LI X, TERESI A, SALVIATI G: Effects of thyroid hormone on fast- and slow-twitch skeletal muscles in young and old rats. J Physiol 481: 149-161, 1994.

LEBERER E, SEEDORF U, PETTE D: Neural control of gene expression in skeletal muscle. Calcium-sequestering proteins in developing and chronically stimulated rabbit skeletal muscles. Biochem J 239: 295-300, 1986.

LI P, WATERS RE, REDFERN SI, ZHANG M, MAO L, ANNEX BH, YAN Z: Oxidative phenotype protects myofibers from pathological insults induced by chronic heart failure in mice. Am J Pathol 170: 599-608, 2007.

MACKRILL JJ: Ryanodine receptor calcium channels and their partners as drug targets. Biochem Pharmacol 79: 1535$1543,2010$.

MACLENNAN DH, WONG PT: Isolation of a calcium-sequestering protein from sarcoplasmic reticulum. Proc Natl Acad Sci U S A 68: 1231-1235, 1971.

MAGUIRE PB, BRIGGS FN, LENNON NJ, OHLENDIECK K: Oligomerization is an intrinsic property of calsequestrin in normal and transformed skeletal muscle. Biochem Biophys Res Commun 240: 721-727, 1997.

MARKS AR, PRIORI S, MEMMI M, KONTULA K, LAITINEN PJ: Involvement of the cardiac ryanodine receptor/calcium release channel in catecholaminergic polymorphic ventricular tachycardia. $J$ Cell Physiol 190: $1-6,2002$.

MELZER W, HERRMANN-FRANK A, LÜTTGAU HC: The role of $\mathrm{Ca}^{2+}$ ions in excitation-contraction coupling of skeletal muscle fibres. Biochim Biophys Acta 1241: 59-116, 1995.

MITCHELL RD, SIMMERMAN HK, JONES LR: $\mathrm{Ca}^{2+}$ binding effects on protein conformation and protein interactions of canine cardiac calsequestrin. J Biol Chem 263: 1376-1381, 1988.

MOORE ED, VOIGT T, KOBAYASHI YM, ISENBERG G, FAY FS, GALLITELLI MF, FRANZINI-ARMSTRONG $\mathrm{C}$ : Organization of $\mathrm{Ca}^{2+}$ release units in excitable smooth muscle of the guinea-pig urinary bladder. Biophys $J$ 87: 1836-1847, 2004.

MURRAY BE, FROEMMING GR, MAGUIRE PB, OHLENDIECK K: Excitation-contraction-relaxation cycle: role of $\mathrm{Ca}^{2+}$-regulatory membrane proteins in normal, stimulated and pathological skeletal muscle (review). Int J Mol Med 1: 677-687, 1998.

MURPHY RM, LARKINS NT, MOLLICA JP, BEARD NA, LAMB GD: Calsequestrin content and SERCA determine normal and maximal $\mathrm{Ca}^{2+}$ storage levels in sarcoplasmic reticulum of fast- and slow-twitch fibres of rat. J Physiol 587: 443-460, 2009.

NOVÁK P, ŠKAJEVA M, MARKOVÁ V, SULIMENKO V, SOUKUP T: Expression of calsequestrin in skeletal and heart muscles of rats with altered thyroid status. Physiol Res 57: 24P, 2008.

NOVÁK P, MARKOVÁ V, SULIMENKO V, SOUKUP T: Calcium binding proteins in skeletal and heart muscles of rats with altered thyroid status after heterochronous isotransplantation. Physiol Res 59: 27P, 2010a.

NOVÁK P, ZACHAROVA G, SOUKUP T: Individual, age and sex differences in fiber type composition of slow and fast muscles of adult Lewis rats: comparison with other rat strains. Physiol Res 59: 783-801, $2010 \mathrm{~b}$.

OBERDORF JA, LEBECHE D, HEAD JF, KAMINER B: Identification of a calsequestrin-like protein from sea urchin eggs. J Biol Chem 263: 6806-6809, 1988. 
PAOLINI C, QUARTA M, NORI A, BONCOMPAGNI S, CANATO M, VOLPE P, ALLEN PD, REGGIANI C, PROTASI F: Reorganized stores and impaired calcium handling in skeletal muscle of mice lacking calsequestrin-1. J Physiol 583: 767-784, 2007.

PARK H, WU S, DUNKER AK, KANG C: Polymerization of calsequestrin. Implications for $\mathrm{Ca}^{2+}$ regulation. $J$ Biol Chem 278: 16176-16182, 2003.

PARK HJ, PARK IY, KIM EJ, YOUN B, FIELDS K, DUNKER AK, KANG CH: Comparing skeletal and cardiac calsequestrin structures and their calcium binding: a proposed mechanism for coupled calcium binding and protein polymerization. $J$ Biol Chem 279: 18026-18033, 2004.

PETTE D: The adaptive potential of skeletal muscle fibers. Can J Appl Physiol 27: 423-448, 2002.

PETTE D, STARON RS: Myosin isoforms, muscle fiber types and transitions. Microsc Res Tech 50: 500-509, 2000.

PETTE D, STARON RS: Transitions of muscle fiber phenotypic profiles. Histochem Cell Biol 115: 359-372, 2001.

POSTMA AV, DENJOY I, HOORNTJE TM, LUPOGLAZOFF J-M, DA COSTA A, SEBILLON P, MANNENS MAM, WILDE AAM, GUICHENEY P: Absence of calsequestrin 2 causes severe forms of catecholaminergic polymorphic ventricular tachycardia. Circ Res 91: e21-e26, 2002.

QIN J, VALLE G, NANI A, NORI A, RIZZI N, PRIORI SG, VOLPE P, FILL M: Luminal $\mathrm{Ca}^{2+}$ regulation of single cardiac ryanodine receptors: insights provided by calsequestrin and its mutants. J Gen Physiol 131: 325-334, 2008.

SACCHETTO R, VOLPE P, DAMIANI E, MARGRETH A: Postnatal development of rabbit fast-twitch skeletal muscle: accumulation, isoform transition and fibre distribution of calsequestrin. J Muscle Res Cell Motil 14: 646-653, 1993.

SANDOW A: Excitation-contraction coupling in skeletal muscle. Pharmacol Rev 17: 265-320, 1965.

SCHIAFFINO S, HANZLIKOVA V, PIEROBON S: Relations between structure and function in rat skeletal muscle fibers. J Cell Biol 47: 107-119, 1970.

SCHIAFFINO S, REGGIANI C: Molecular diversity of myofibrillar proteins: gene regulation and functional significance. Physiol Rev 76: 371-423, 1996.

SCHIAFFINO S: Fibre types in skeletal muscle: a personal account. Acta Physiol (Oxf) 199: 451-463, 2010.

SCOTT BT, SIMMERMAN HK, COLLINS JH, NADAL-GINARD B, JONES LR: Complete amino acid sequence of canine cardiac calsequestrin deduced by cDNA cloning. J Biol Chem 263: 8958-8964, 1988.

SHEN X, FRANZINI-ARMSTRONG C, LOPEZ JR, JONES LR, KOBAYASHI YM, WANG Y, KERRICK WGL, CASWELL AH, POTTER JD, MILLER T, ALLEN PD, PEREZ CF: Triadins modulate intracellular $\mathrm{Ca}^{2+}$ homeostasis but are not essential for excitation-contraction coupling in skeletal muscle. $J$ Biol Chem 282: 37864-37874, 2007.

SHENOY R, KLEIN I, OJAMAA K: Differential regulation of SR calcium transporters by thyroid hormone in rat atria and ventricles. Am J Physiol Heart Circ Physiol 281: H1690-H1696, 2001.

SIMONIDES WS, VAN HARDEVELD C: The effect of hypothyroidism on sarcoplasmic reticulum in fast-twitch muscle of the rat. Biochim Biophys Acta 844: 129-141, 1985.

SMERDU V, SOUKUP T: Demonstration of myosin heavy chain isoforms in rat and humans: the specificity of seven available monoclonal antibodies used in immunohistochemical and immunoblotting methods. Eur J Histochem 52: 179-190, 2008.

SOUKUP T, JIRMANOVÁ I: Regulation of myosin expression in developing and regenerating extrafusal and intrafusal muscle fibers with special emphasis on the role of thyroid hormones. Physiol Res 49: 617-633, 2000.

SOUKUP T, ZACHAROVA G, SMERDU V, JIRMANOVÁ I: Body, heart, thyroid gland and skeletal muscle weight changes in rats with altered thyroid status. Physiol Res 50: 619-626, 2001.

SOUKUP T, ZACHAŘOVÁ G, SMERDU V: Fibre type composition of soleus and extensor digitorum longus muscles in normal female inbred Lewis rats. Acta Histochem 104: 399-405, 2002.

SOUKUP T, SMERDU V, ZACHAŘOVÁ G: Fiber type composition of unoperated rat soleus and extensor digitorum longus muscles after unilateral isotransplantation of a foreign muscle in long-term experiments. Physiol Res 58: 253-262, 2009.

SZEGEDI C, SÁRKÖZI S, HERZOG A, JÓNA I, VARSÁNYI M: Calsequestrin: more than 'only' a luminal $\mathrm{Ca}^{2+}$ buffer inside the sarcoplasmic reticulum. Biochem J 337: 19-22, 1999. 
TERENTYEV D, NORI A, SANTORO M, VIATCHENKO-KARPINSKI S, KUBALOVA Z, GYORKE I, TERENTYEVA R, VEDAMOORTHYRAO S, BLOM NA, VALLE G, NAPOLITANO C, WILLIAMS SC, VOLPE P, PRIORI SG, GYORKE S: Abnormal interactions of calsequestrin with the ryanodine receptor calcium release channel complex linked to exercise-induced sudden cardiac death. Circ Res 98: 1151-1158, 2006.

TERENTYEV D, KUBALOVA Z, VALLE G, NORI A, VEDAMOORTHYRAO S, TERENTYEVA R, VIATCHENKO-KARPINSKI S, BERS DM, WILLIAMS SC, VOLPE P, GYORKE S: Modulation of SR Ca release by luminal $\mathrm{Ca}$ and calsequestrin in cardiac myocytes: effects of CASQ2 mutations linked to sudden cardiac death. Biophys J 95: 2037-2048, 2008.

TOMELLERI G, PALMUCCI L, TONIN P, MONGINI T, MARINI M, L'ERARIO R, RIZZUTO N, VATTEMI G: SERCA1 and calsequestrin storage myopathy: a new surplus protein myopathy. Brain 129: 2085-2092, 2006.

VADÁSZOVÁ A, ZACHAŘOVÁ G, MACHÁČOVÁ K, JIRMANOVÁ I, SOUKUP T: Influence of thyroid status on the differentiation of slow and fast muscle phenotypes. Physiol Res 53 (Suppl 1): S57-S61, 2004.

VADÁSZOVÁ A, HUDECOVÁ S, KRIŽANOVÁ O, SOUKUP T: Levels of myosin heavy chain mRNA transcripts and content of protein isoforms in the slow soleus muscle of 7-month-old rats with altered thyroid status. Physiol Res 55: 221-225, 2006a.

VADÁSZOVÁ A, HUDECOVÁ S, KRIŽANOVÁ O, SOUKUP T: Levels of myosin heavy chain mRNA transcripts and protein isoforms in the fast extensor digitorum longus muscle of 7-month-old rats with chronic thyroid status alterations. Physiol Res 55: 707-710, 2006 b.

VADÁSZOVÁ-SOUKUP A, SOUKUP T: Dual role of thyroid hormones in rat soleus muscle MyHC isoform expression. Physiol Res 56: 833-836, 2007.

VOLPE P, VILLA A, DAMIANI E, SHARP AH, PODINI P, SNYDER SH, MELDOLESI J: Heterogeneity of microsomal $\mathrm{Ca}^{2+}$ stores in chicken Purkinje neurons. EMBO J 10: 3183-3189, 1991.

VOLPE P, MARTINI A, FURLAN S, MELDOLESI J: Calsequestrin is a component of smooth muscles: the skeletaland cardiac-muscle isoforms are both present, although in highly variable amounts and ratios. Biochem J 301: 465-469, 1994.

WANG S, TRUMBLE WR, LIAO H, WESSON CR, DUNKER AK, KANG CH: Crystal structure of calsequestrin from rabbit skeletal muscle sarcoplasmic reticulum. Nat Struct Biol 5: 476-483, 1998.

WEI L, VARSÁNYI M, DULHUNTY AF, BEARD NA: The conformation of calsequestrin determines its ability to regulate skeletal ryanodine receptors. Biophys $J$ 91: 1288-1301, 2006.

WEI L, HANNA AD, BEARD NA, DULHUNTY AF: Unique isoform-specific properties of calsequestrin in the heart and skeletal muscle. Cell Calcium 45: 474-484, 2009.

ZARAIN-HERZBERG A, FLIEGEL L, MACLENNAN DH: Structure of the rabbit fast-twitch skeletal muscle calsequestrin gene. J Biol Chem 263: 4807-4812, 1988.

ZACHAŘOVÁ G, KUBÍNOVÁ L: Stereological methods based on point counting and unbiased counting frames for two-dimensional measurements in muscles: comparison with manual and image analysis methods. $J$ Muscle Res Cell Motil 16: 295-302, 1995.

ZACHAŘOVÁ G, KNOTKOVÁ-URBANCOVÁ J, HNÍK P, SOUKUP T: Nociceptive atrophy of the rat soleus muscle induced by bone fracture: a morphometric study. J Appl Physiol 82: 552-557, 1997.

ZACHAŘOVÁ G, MRÁČKOVÁ K, JIRMANOVÁ I, SOUKUP T: Stereological evaluation of the soleus muscle isografted into fast extensor digitorum longus (EDL) muscle in rats with different thyroid status. Gen Physiol Biophys 18 (Suppl 1): 84-86, 1999.

ZACHAŘOVÁ G, VADÁSZOVÁ A, SMERDU V, ASMUSSEN G, SOUKUP T: The effect of a unilateral muscle transplantation on the muscle fiber type and the MyHC isoform content in unoperated hind limb slow and fast muscles of the inbred Lewis rats. Physiol Res 54: 691-696, 2005.

ZHANG L, KELLEY J, SCHMEISSER G, KOBAYASHI YM, JONES LR: Complex formation between junctin, triadin, calsequestrin, and the ryanodine receptor. Proteins of the cardiac junctional sarcoplasmic reticulum membrane. J Biol Chem 272: 23389-23397, 1997. 